\title{
Anatomy of the main stem of soybean plants submitted to the removal of the stem apical meristem
}

\author{
Guilherme Jordan Souza Véras ${ }^{1}\left(\mathbb{D}\right.$, Éder Matsuo $^{2, *}{ }^{\mathbb{C}}$, Jaqueline Dias- \\ Pereira $^{3}{ }^{(0}$, Silvana da Costa Ferreira ${ }^{4}(0)$ and Mirlem Gonçalves Rocha ${ }^{3}[$
}

\begin{abstract}
${ }^{1}$ Agrarian Sciences Institute, Federal University of Viçosa, Rio Paranaíba Campus, Biostatistics Laboratory, Highway MG 230, Km 7, PO Box 22, Rio Paranaiba, MG, Brazil, CEP 38810-000. ${ }^{2}$ Biostatistics Laboratory, Technological and Exact Sciences Institute, Federal University of Viçosa, Rio Paranaíba Campus, Highway MG 230, Km 7, PO Box 22, Rio Paranaiba, MG, Brazil, CEP 38810-000. ${ }^{3}$ Histotechnic Laboratory, Biological and Health Sciences Institute, Federal University of Viçosa, Rio Paranaíba Campus, Highway MG 230, Km 7, PO Box 22, Rio Paranaiba, MG, Brazil, CEP 38810-000. ${ }^{4}$ Plant Systematics Laboratory, Biological and Health Sciences Institute, Federal University of Viçosa, Rio Paranaíba Campus, Highway MG 230, Km 7, PO Box 22, Rio Paranaiba, MG, Brazil, CEP 38810-000.

*Corresponding author, E-mail: edermatsuo@ufv.br
\end{abstract}

\section{ABSTRACT}

Some plant species allow the cutting of the apical meristem in order to assist activities of genetic improvement programs, among them is the soybean. The objective was to verify if the removal of the apical meristem of soybean plants induces any alteration in the stem anatomy, since it was verified that the removal of the apical meristem reduces the need for tutoring of the plants cultivated under greenhouse conditions. The experiment was conducted with plants of the BRSMG $752 \mathrm{~S}$ cultivar and the treatments consisted of sections of the hypocotyl region of plants that had undergone apical meristem removal at the V2 development stage and of plants without apical meristem removal. The permanent slides were processed following the usual methodologies in plant anatomy. Descriptions and measurements of anatomical tissues were made for comparison between treatments. Plants with removal presented epidermis as a covering tissue until 20 days after the V2 development stage, while plants without removal of the apical meristem presented it until 30 days after V2. Periderm was observed only in plants with removal, and this feature was not evident in plants without removal until 30 days after V2. There was formation of secondary vascular tissues in the collections 30 days after removal (V2 stage). Thus, we conclude that the removal of the apical meristem accelerates the secondary development in hypocotyls of soybean plants grown under greenhouse conditions.

Keywords: Glycine max, cultivation, densification, interaction, shading, distinctiveness. 


\section{INTRODUCTION}

Soybean in Brazil is grown on 38.502 million hectares with a total production of 135.409 million tons in the 2020/2021 crop year, resulting in an average productivity of 3,517 kg/ha (Ferreira et al., 2020; Empresa Brasileira de Pesquisa Agropecuária [EMBRAPA], 2021). The increase in national production has occurred due to improvements in management techniques and genetic improvement programs (Oda et al., 2015). Associated with productivity (the main characteristic of a cultivar) one can consider precocity, resistance/tolerance to biotic and abiotic characteristics to which the plant may be subjected and the introgression of genes of interest in the genotype to be released as a cultivar (Bomtempo, Matsuo, \& Oda, 2021; Matsuo, Borém, \& Sediyama, 2021).

The cultivation of soybeans under greenhouse conditions is different from field cultivation, and in some cases may require tutoring of the plants (Tancredi, Sediyama, Reis, Cecon, \& Teixeira, 2006). A technique that favors the conduction in high populations of plants in breeding programs increasing the possibility of working in limited areas, such as in a greenhouse, is the removal of the apical meristem of the plants (Toledo, Tancredi, Sediyama, Ribeiro Junior, \& Reis, 2009). In this sense, the removal of the apical meristem influences the growth of soy plants, reducing the number of nodes of the main stem, the plant height and the insertion height of the first pod, especially when performed at $25 \mathrm{~cm}$ of height (Tancredi et al., 2006). The increase in diameter of the stem of soy plants is interesting, because the stem becomes more robust and can develop a greater amount of side branches making the plants more tolerant to lodging (Dias, Lisboa, Ferreira, \& Rocha, 2021)

The use of plant anatomy techniques has been applied in soybean culture with several objectives such as:

a) the analysis of leaves infected by the fungus Phakopsora pachyrhizi (Mussury, Betoni, Silva, \& Scalon, 2012),

b) a comparative anatomical study in the leaves of different soybean cultivars (Lourenço, Vasconcelos Filho, Vasconcelos, \& Campos, 2011),

c) in the study of the impact of soil compaction on soybean root growth (Moraes et al., 2020),

d) in the morpho-anatomical characterization of seeds with or without weathering damage (Pinheiro et al., 2021),

e) in the study of anatomical alteration in the stem and root of soybean plants submitted to salt stress data (Silva, Batista, \& Lobato, 2021), among others.

However, it requires accurate knowledge of the stem anatomy submitted to the removal of the apical meristem.

Thus, our objective was to study the alterations in the stem anatomy of soybean plants submitted to the removal of the apical meristem.

\section{MATERIAL AND METHODS}

The experiment was developed in a greenhouse ( $\left.19^{\circ} 11^{\prime} 37^{\prime \prime} \mathrm{S}, 46^{\circ} 14^{\prime} 50^{\prime \prime} \mathrm{W}\right)$ located at 1,067 m, whose climate is classified as cWa (Köppen Classification). The cultivar that was used was the BRSMG 752S, which has indeterminate growth habit and relative maturity of 7.5 (EMBRAPA, 2008). Sowing occurred on March 15, 2018 in $3 \mathrm{dm}^{3}$ pots, filled $3 / 4$ of their volume with soil and $1 / 4$ remaining with tanned manure. After germination, the plants were conducted according to the needs of the culture, with daily soil irrigation and pest and disease control (Sediyama, 2009). 
The experiment was conducted in an entirely randomized design with six repetitions. The treatments consisted of plants that had undergone removal of the apical meristem (with removal) at the V2 development stage (Fehr \& Caviness, 1977) and plants without removal of the apical meristem (without removal), as shown in Table 1.

Table 1. Details of the treatments (times of collection of hypocotyl) and their respective codifications.

\begin{tabular}{ll}
\hline Codification & Detailing \\
\hline With removal & Removal of the apical meristem of plants at the V2 \\
\hline V2+OD & Collection of the hypocotyl at 0 day after the V2 \\
V2+20D & Collection of the hypocotyl at 20 days after the V2 \\
V2+40D & Collection of the hypocotyl at 40 days after the V2 \\
V2+60D & Collection of the hypocotyl at 60 days after the V2 \\
V2+80D & Collection of the hypocotyl at 80 days after the V2 \\
\hline Without removal & Without removal of the apical meristem of plants \\
V2+0D & Collection of the hypocotyl at 0 day after the V2 \\
V2+10D & Collection of the hypocotyl at 10 days after the V2 \\
V2+20D & Collection of the hypocotyl at 20 days after the V2 \\
V2+30D & Collection of the hypocotyl at 30 days after the V2 \\
\hline
\end{tabular}

${ }^{1}$ Developmental stage scale according to Fehr and Caviness (1977).

For the anatomical analyses, the materials were collected from the upper part of the hypocotyl. For this, the first $5 \mathrm{~mm}$ were discarded, and the $5 \mathrm{~mm}$ long hypocotyl was used for laboratory analysis, namely, between 5 to $10 \mathrm{~mm}$ from the cotyledonary node towards the ground. The samples of hypocotyls from each treatment were fixed in $\mathrm{FAA}_{50 \%}$ (formaldehyde, acetic acid and ethyl alcohol 50\%, in a ratio of 5:5:90, v:v:v), for 48 hours under immersion (Johansen, 1940). Afterwards they were dehydrated in increasing ethyl series and included in methacrylate (Historesin, Leica Instruments, Heidelberg, Germany). Cross-sections of $5 \mu \mathrm{m}$ thickness were made on an automatic feed rotary microtome (Leica, model RM2255). The slides were stained with toluidine blue (O'Brien \& McCully, 1981) and mounted with Permount. The images were scanned on a microscope (Olympus) BX 41 with a digital camera coupled with a U-PHOTO system (Olympus Q color 3 ).

For each collection time (treatment) it was used two repetitions, in other words, two slides, each obtained from different plants in the same treatment. From each slide, two sections were analyzed, and, in each section, it was measured three fields of each slide. In each field we evaluated the thickness, in micrometers, of epidermis and/or periderm, collenchyma, cortical parenchyma, total thickness of the cortex, primary phloem, secondary phloem, cambium, secondary xylem, primary xylem, and pith. In addition, the area of the secondary xylem was determined.

The Shapiro-Wilk test for normality $(p<0.05)$ indicated that the data did not fit the normal distribution. Therefore, the Kruskal-Wallis test followed by Dunn's test was applied to compare the collection epochs and the Mann-Whitney test to compare the effect of apical meristem removal, at $5 \%$ significance level, using the $R$ Program (R Core Team, 2018). 


\section{RESULTS AND DISCUSSION}

All plants that were exactly at the V2 developmental stage (V2+OD) showed epidermis with stomata and tector trichomes; angular collenchyma consisting of only one layer of cells; cortex of 6 to 9 layers, including aerenchyma and monocrystals were observed in the parenchyma cells of the primary phloem (Figure $1 \mathrm{~A})$. At this collection time (exactly at the V2 developmental stage) the formation of secondary phloem was not verified; however, it was observed that the cambium and secondary xylem and primary xylem were grouped in poles and parenchymatic pith. For the plants with removal (Figures $1: A, B, D$ and $E$ ), the epidermis and cortex were only present for the $\mathrm{V} 2+0 \mathrm{D}$ and $\mathrm{V} 2+20 \mathrm{D}$ collections (Figure $1: \mathrm{A}$ and $\mathrm{B}$ ).

From V2+40D, in other words, 40 days after the V2 developmental stage, the epidermis showed to be detached, and its replacement by the periderm began (Figure 1: D and Figure 2: A, C and E). In plants without removal (Figure 1: C and F), the epidermis and cortex were present until the last collection time V2+30D (Figure 1: $F$ and Figure 2: $B$ and $D$ ). The exclusion of the epidermis and cortex at $V 2+40 D$ in plants with removal probably induced secondary growth more rapidly.

Cortex and primary phloem showed significant differences in plants with and without removal, with lower values occurring at $\mathrm{V} 2+20 \mathrm{D}$ for plants without removal (Figure 1: $\mathrm{C}$ and Figure 2: $\mathrm{C}, \mathrm{D}$ and $\mathrm{G}, \mathrm{H}$ ). The measurements for these tissues still showed a reduction from $V 2+O D$ to $V 2+20 D$ (Figure 2: $D$ and $H$ ). At this time the cambium band was already active producing the secondary vascular tissues, and in their development, these may have compressed the peripheral tissues, such as the cortex and primary phloem region. In plants with removal, it was noted that the primary phloem showed higher values at $\mathrm{V} 2+40 \mathrm{D}, \mathrm{V} 2+60 \mathrm{D}$ and $\mathrm{V} 2+80 \mathrm{D}$ (Figure 2: $\mathrm{G})$. It was at this time $(\mathrm{V} 2+40 \mathrm{D})$ when the epidermis and cortex of plants with removal were replaced by the periderm, which may also have contributed to the loss and decrease of phloem (Figure 1: D and Figure 2: A, C and F). The presence of the periderm only occurred in plants with removal at $\mathrm{V} 2+40 \mathrm{D}$ and its growth did not change between V2+60 and V2+80D (Figure 1: D, E and F and Figure 2: $E$ and F).

At V2+10D (without removal) the secondary phloem was in its formation, however, at $\mathrm{V} 2+20 \mathrm{D}$ and $\mathrm{V} 2+30 \mathrm{D}$ (without removal) it was in the shape of an inverted triangle (Figure 1: $\mathrm{C}$ and F), in other words, in the form organized by the formation of rays in the secondary xylem and continuity of these in the phloem. In both conditions, with removal or not, there was greater thickness for secondary phloem as the collections of hypocotyls progressed. However, no significant difference in thicknesses occurred between treatments at V2+OD and V2+20D, when comparing with and without removal (Figure 2: I and J). It was also observed for secondary phloem, that in plants submitted to removal there was large growth in length from V2+20D to V2+40D, at which time the secondary growth of these plants was fully established (Figure 1: D and Figure 2: I), i.e., no statistical difference until V2+80D. 


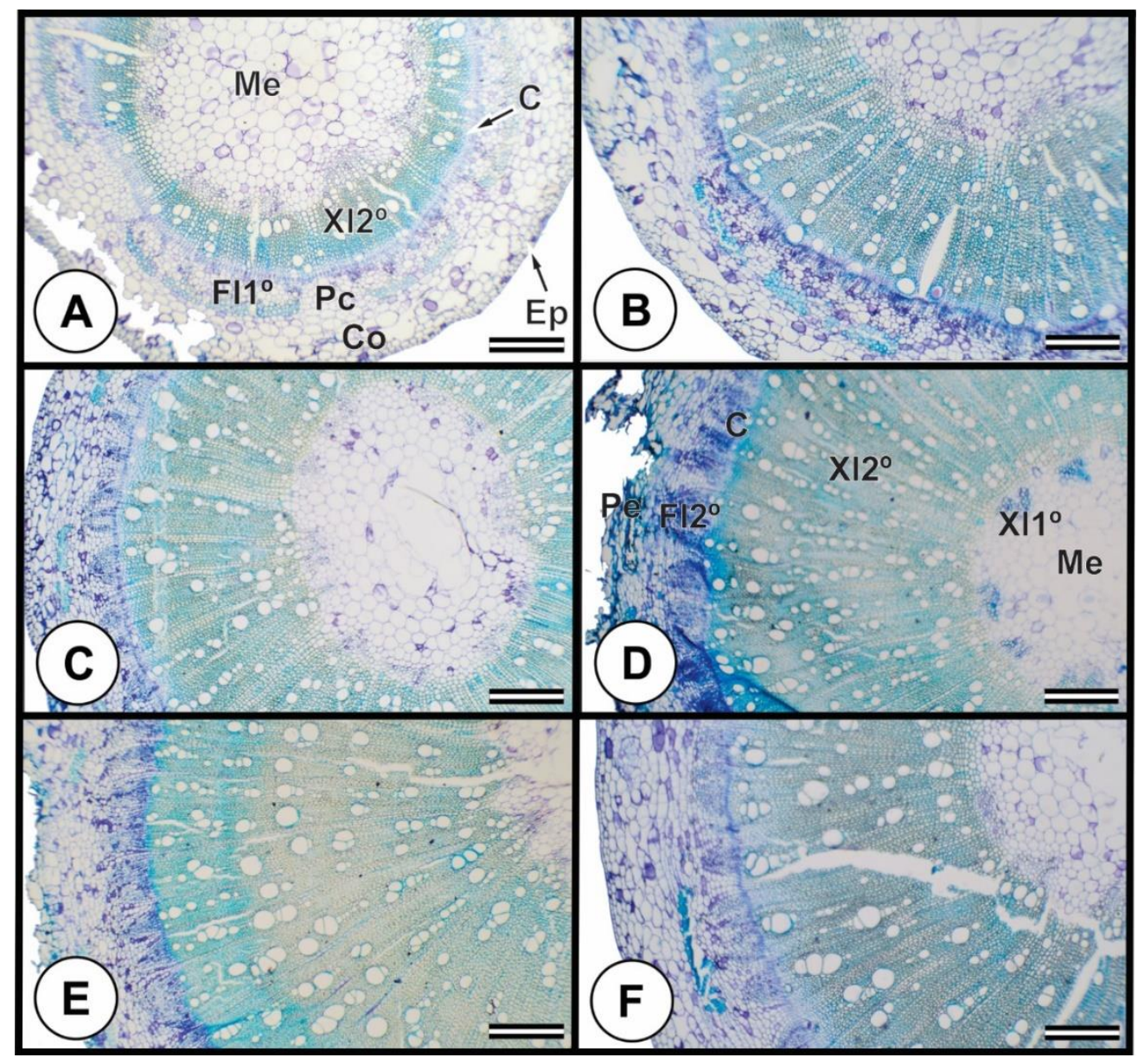

Figure 1. Anatomy of the hypocotyl of soybean plants (cross sections), submitted to Apical Meristem Removal (RMA) or Without Apical Meristem Removal (SRMA). Hypocotyl collection times: A: V2+OD (V2 developmental stage); B: V2+20D (20 days after V2 developmental stage) with removal; C: V2+20D (20 days after V2 developmental stage) without removal; D: V2+40D (40 days after development stage V2) with removal; E: V2+60D (60 days after development stage V2) with removal; F: V2+30D (30 days after development stage V2) without removal. C: cambium, Co: collenchyma, Ep: epiderm, Fl2o: secondary phloem, Me: pith, PC: cortical parenchyma, Pe: periderm, Xi1ㅇ: primary xylem, Xi2o: secondary xylem. Bar (scale) $=100 \mu \mathrm{m}$.

For both cases, with and without removal, the cambium tended to be thinner after the V2 developmental stage. In the collections without removal, this reduction was seen at V2+10D. With removal, a lower cambium thickness was observed at $V 2+20 D$. After these times for both (with and without removal) the cambium showed growth, so the measurements between $V 2+0 D$ and $V 2+20 D$ were significantly different, with the $\mathrm{V} 2+20 \mathrm{D}$ being smaller (Figure 3: A and B).

Secondary xylem showed growth in plants with or without removal, but at V2+20D, plants without removal showed greater thickness of this tissue (Figure 1: C and Figure 3: $C$ and D). Still, with removal the secondary xylem showed significant growth. At $\mathrm{V} 2+20 \mathrm{D}$ it showed thickness at around $750 \mu \mathrm{m}$ and at $\mathrm{V} 2+40 \mathrm{D}$ around $1500 \mu \mathrm{m}$, reaching its maximum values at V2+60D (Figure 3: C). Another factor that may have led to this higher growth after V2+20D, is the simultaneous growth with the cambium resulting in higher production activity of the secondary vascular tissues (Figure 3: $A$ and B). From V2+40D no difference was identified with the subsequent seasons $(\mathrm{V} 2+60 \mathrm{D}$ and $\mathrm{V} 2+80 \mathrm{D})$. The last collections for plants without removal were at $\mathrm{V} 2+30 \mathrm{D}$, so it was not possible to verify if their growth also 
increased after this time. For all plants, with or without removal, there was no difference in the primary xylem thickness between collection times. There was also no significant difference between "with removal" and "without removal" in the collections at V2+OD and V2+20D (Figure 3: $\mathrm{E}$ and F).

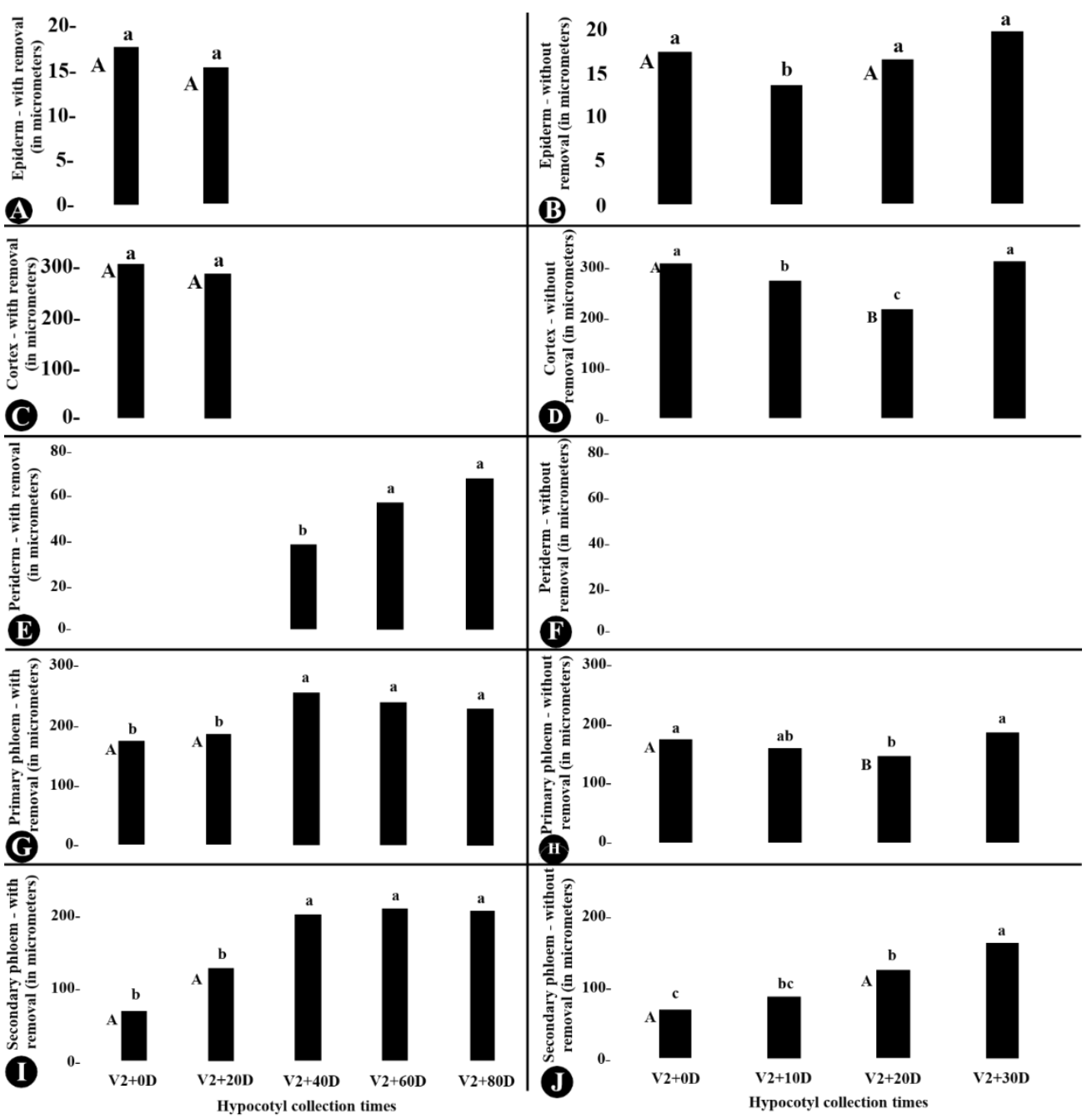

Figure 2. Anatomical tissues of the hypocotyl of soybean plants submitted to Apical Meristem Removal (with AMR) or Without Apical Meristem Removal (without AMR). A: epidermis of plants with $A M R$; B: epidermis of plants without AMR; C: cortex of plants with AMR; D: cortex of plants without $A M R$; $E$ : periderm of plants with AMR; F: periderm of plants without AMR; G: primary phloem of plants with AMR; $\mathrm{H}$ : primary phloem of plants without AMR; I: secondary phloem of plants with AMR; J: secondary phloem of plants without AMR. Epochs of hypocotyl collection: V2+OD ( 0 day after V2 development stage); V2+10D (10 days after V2 development stage); V2+20D (20 days after V2 development stage); $\mathrm{V} 2+30 \mathrm{D}$ (30 days after $\mathrm{V} 2$ development stage); $\mathrm{V} 2+40 \mathrm{D}$ (40 days after V2 development stage); V2+60D (60 days after V2 development stage); and V2+80D (80 days after V2 development stage). Uppercase letters compare "with removal" and "without removal," separately for the V2+OD and V2+20D seasons by Mann-Whitney's Test $(\alpha=0.05)$ and lowercase letters compare collection seasons within each individualized plot by Dunn's Test $(\alpha=0.05)$. 


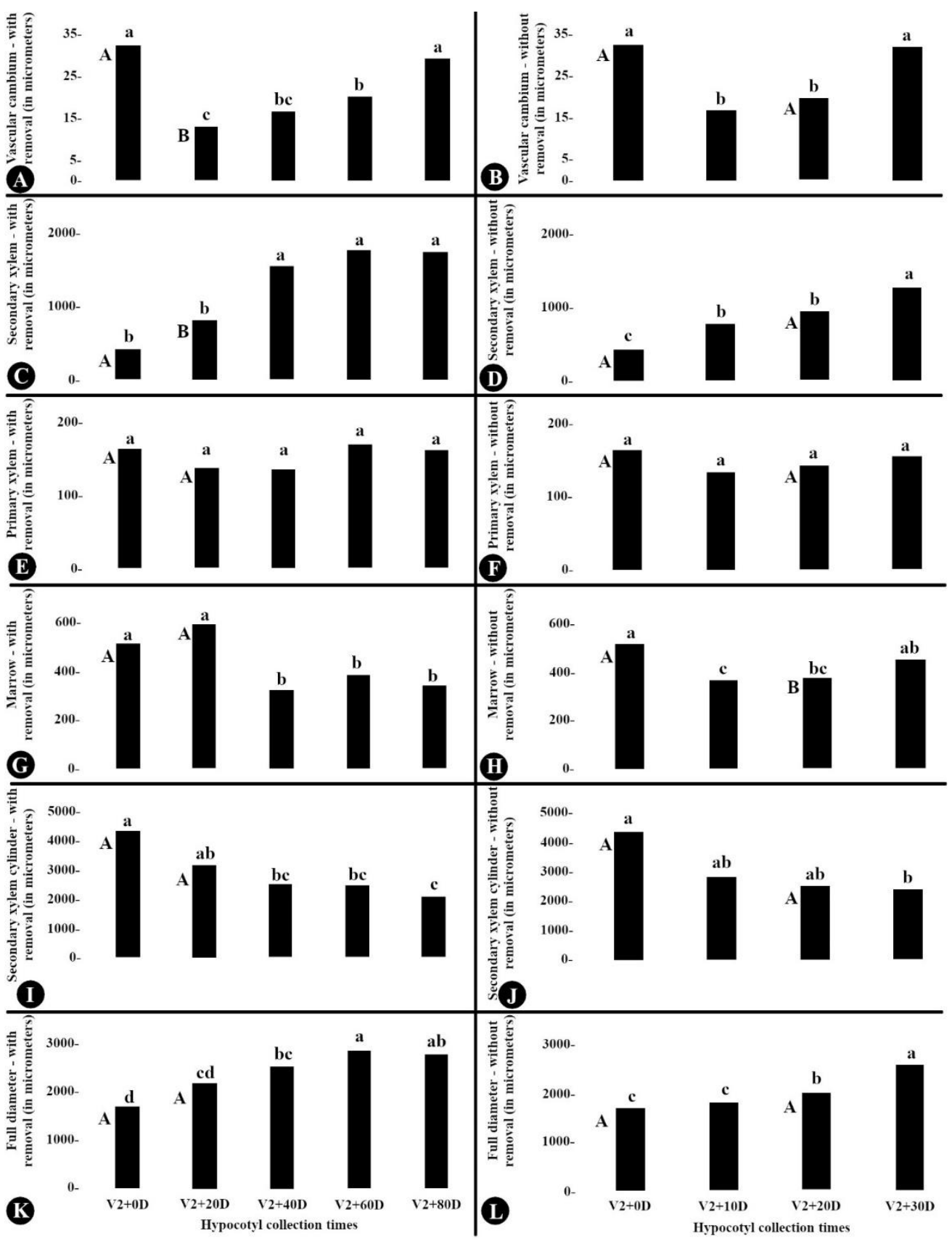

Figure 3. Anatomical tissues of the hypocotyl of soybean plants submitted to Apical Meristem Removal (with AMR) or Without Apical Meristem Removal (without AMR). A: cambium of plants with AMR; B: cambium of plants without AMR; C: secondary xylem of plants with AMR; D: secondary xylem of plants without AMR; E: primary xylem of plants with AMR; F: primary xylem of plants without AMR; G: pith of plants with AMR; $H$ : pith of plants without AMR; I: secondary xylem cylinder of plants with RMA; J: secondary xylem cylinder of plants without RMA; K: total diameter of plants with RMA; L: total diameter of plants without RMA. Moments of hypocotyl collections: V2+OD ( 0 day after V2development stage); V2+10D (10 days after V2development stage); V2+20D (20 days after V2development stage); V2+30D (30 days after V2development stage); V2+40D (40 days after V2development stage); V2+60D (60 days after V2development stage); and V2+80D (80 days after V2development stage). Uppercase letters compare "with RMA" and "without RMA", separately for the $\mathrm{V} 2+0 \mathrm{D}$ and $\mathrm{V} 2+20 \mathrm{D}$ seasons by Mann-Whitney's Test $(\alpha=0.05)$ and lowercase letters compare the collection seasons within each individual graph by Dunn's Test $(\alpha=0.05)$. 
What could be noticed is that the plants without removal initially presented greater development and formation in the secondary xylem tissues, while in plants with removal they presented a greater cortex and primary phloem region. In the collections of $\mathrm{V} 2+40 \mathrm{D}$ when there was an increase in the cambium range there was a compensation of the units under removal, occurring an increase in the growth of secondary xylem and phloem until its stabilization in V2+60D (Figure 1: B and C).

At $\mathrm{V} 2+0 \mathrm{D}$ and $\mathrm{V} 2+20 \mathrm{D}$, the plants with removal showed greater values of pith thickness compared to the other collection periods (Figure 1: B and D and Figure 3: $G)$ that already showed secondary growth and, with this, a decrease in pith. In plants without removal from V2+20D to V2+30D pith growth still occurred (Figure 3: $\mathrm{H})$. Along with this fact, the measurements for secondary xylem area plus pith area also reduced, possibly due to the reduction in pith thickness. These reductions occurred for both treatments, with and without removal, with the smallest measurements being the last field collections (Figure 3: I and J).

For the total diameter of the stem, of plants with and without removal, the most advanced collections presented larger values in relation to the V2 development stage (Figure 3: $\mathrm{K}$ and $\mathrm{L}$ ). This growth occurs naturally and with advancement of its development, the origin of secondary vascular tissues by the cambium, resulting in a greater stem thickness.

Plant height and height of the first pod insertion were reduced with the removal of the apical meristem (Toledo et al., 2009). The response for these traits was similar and the number of nodes of the main stem was also reduced as a result of reduced plant size (Tancredi et al., 2006). Removal of the apical meristem at 25, 50 and $75 \mathrm{~cm}$ was effective in reducing the masses, indicating less growth of these compared to the control (no cutting) (Tancredi, Sediyama, Reis, Cecon, \& Teixeira, 2004).

It is noted that plant growth after meristem removal is reduced (Barzan, Freiria, Nascimento Junior, \& Prete, 2016). These authors observed in two treatments, that plants submitted to cuts above the cotyledonary node at development stage $\mathrm{V} 1$ and above the primary leaf node at stage $\mathrm{V} 2$ had reduced height and greater diameter of the plant neck. Contrary to the observations of other researchers, greater branching occurred in the witness, or in the treatment that received cutting of only the cotyledons at VC stage (Barzan et al., 2016). The works found that plants with removal presented lower height, one of the possible justifications is the induction of secondary growth more quickly compared to plants without removal (Tancredi et al., 2004; Tancredi et al, 2006).

\section{CONCLUSION}

The removal of the apical meristem accelerates the secondary development in hypocotyl of soybean plants grown under greenhouse conditions.

\section{REFERENCES}

Barzan, R. R., Freiria, G. H., Nascimento Junior, V. C., \& Prete, C. E. C. (2016). Remoção de estruturas vegetativas nos estádios iniciais sobre características produtivas e morfofisiológicas da soja. Cultura Agronômica, 25(1), 17-24. https://doi.org/10.32929/2446-8355.2016v25n1p17-24

Bomtempo, G. L., Matsuo, É., \& Oda, M. C. (2021). Vegetative and productive performance of two soybean cultivars at different plant densities. Agronomy Science and Biotechnology, 7, 1-12. https://doi.org/10.33158/asb.r133.v7.2021 
Dias, G. H. O., Lisboa, L. A. M., Ferreira, J. P. D. S., \& Rocha, E. A. (2021). Development of indetermined growth soy cultivars after apical pruning. Research, Society and Development, 10(5): e46510513688. https://doi.org/10.33448/rsd-v10i5.13688.

EMBRAPA - Empresa Brasileira de Pesquisa Agropecuária. (2008). Soja - BRSMG $752 S$.

https://www.embrapa.br/documents/1355202/1529289/BRSMG752S_convenci onal.pdf/f6ad20ed-1799-4b12-a26a-2fbe5038ec89

EMBRAPA - Empresa Brasileira de Pesquisa Agropecuária. (2021). Soja em números (safra 2020/21): dados econômicos. Londrina: Embrapa soja. https://www.embrapa.br/soja/cultivos/soja1/dados-economicos. Acesso em 25/06/2021.

Fehr, W. R., \& Caviness, C. E. (1977). Stage of soybean development (Special Report 80). Ames: lowa State University. Retrieved from http://lib.dr.iastate.edu/specialreports/87

Ferreira, L. L., Carvalho, P. R. V., Fernandes, M. S., Silva, J. G., Carvalho, I. R., \& Lautenchleger, F. (2020). Neural network and canonical interrelationships for the physiological aspects of soybean seedlings: effects of seed treatment. Agronomy Science and Biotechnology, 6, 1-11. https://doi.org/10.33158/asb.r116.v6.2020

Johansen, D. A. (1940). Plant microtechnique. New York: McGraw-Hill Book Company Inc.

Lourenço, H. A. O., Vasconcelos Filho, S. C., Vasconcelos, J. M., \& Campos, H. D. (2011). Anatomia foliar de diferentes cultivares de soja e sua relação com incidência e severidade de doenças. Global science and technology, 4(3), 37-47. https://rv.ifgoiano.edu.br/periodicos/index.php/gst/article/view/368

Matsuo, E., Borém. A., \& Sediyama T. (2021). Desenvolvimento de Cultivares. In: Sediyama, T., Matsuo, E., Borém, A. (Eds.), Melhoramento da Soja no Brasil. Londrina-PR: Editora Mecenas, p. 93-102

Moraes, M. T., Debiasi, H., Franchini, J. C., Mastroberti, A. A., Levien, R., Leitner, D., \& Schenepf, A. (2020). Soil compaction impacts soybean root growth in an Oxisol from subtropical Brazil. Soil and Tillage Research, 200, 104611. doi.org/10.1016/j.still.2020.104611

Mussury, R. M., Betoni, R., Silva, M. A., \& Scalon S. P. Q. (2012). Anatomia foliar de soja infectada por Phakopsora pachyrhizi H. Sydow \& Sydow e tratadas com extratos vegetais. Revista Brasileira de Plantas Medicinais, 14(1): 18-25. https://doi.org/10.1590/S1516-05722012000100004

O'Brien, T. P., \& Mccully, M. E. (1981). The study of plant structure principles and select methods. Melbourne: Termarcarphy Ltda. 
Oda, M. C., Sediyama, T., Matsuo, É., Cruz, C. D., Barros, E. G., \& Ferreira, M. F. S. (2015). Phenotypic and molecular traits diversity in soybean launched in forty years of genetic breeding. Agronomy Science and Biotechnology, 1(1), 1-9. https://doi.org/10.33158/ASB.2015v1i1p1

Pinheiro, D. T., Dias, D. C. F., Medeiros, A. D. M., Ribeiro, P. O., Silva, F. L., \& Silva, L. J. (2021). Weathering deterioration in pre-harvest of soybean seeds: physiological, physical, and morpho-anatomical changes. Scientia Agricola, 78(1): e20200166. doi.org/10.1590/1678-992X-2020-0166

R Core Team. (2018). R: A language and environment for statistical computing. Vienna, Austria: R Foundation for Statistical Computing. Retrieved from: www.R-project.org/

Sediyama, T. (2009). Tecnologia de produção de sementes de soja. Londrina: Mecenas.

Silva, B. R. S., Batista, B. L., \& Lobato, A. K. S. (2021). Anatomical changes in stem and root of soybean plants submitted to salt stress. Plant Biology, 23:57-65. doi.org/10.1111/plb.13176

Tancredi, F. D., Sediyama, T., Reis, M. S., Cecon, P. R., \& Teixeira, R. C. (2006). Efeito da remoção do meristema apical no crescimento e desenvolvimento de plantas de soja em condições de casa de vegetação. Bioscience Journal, 22(2), 53-60. http://www.seer.ufu.br/index.php/biosciencejournal/article/view/6716/4427

Tancredi, F. D., Sediyama, T., Reis, M. S., Cecon, P. R., \& Teixeira, R, C. (2004). Influência da remoção do meristema apical sobre os componentes de produtividade em populações de plantas de soja. Acta Scientiarum. Agronomy, 26(1), 113-119. https://doi.org/10.4025/actasciagron.v26i1.1968

Toledo, M. R., Tancredi, F. D., Sediyama, T., Ribeiro Junior, J. I., \& Reis, M. S. (2009). Remoção do meristema apical e adensamento em plantas de soja visando sua utilização no método descendente de uma única semente. Acta Scientiarum. Agronomy, 31(1), 113-119. https://doi.org/10.4025/actasciagron.v31i1.6656 